\title{
The Current Situation and Sustainable Development of Water Resources in Bangladesh
}

\author{
Sefat Ara Nadira, Li Shixiang \\ School of Public Administration, China University of Geosciences, Wuhan, P. R. China \\ Email address: \\ shifatcug@yahoo.com (S. A. Nadira), 28742962@qq.com (Li Shixiang)
}

To cite this article:

Sefat Ara Nadira, Li Shixiang. The Current Situation and Sustainable Development of Water Resources in Bangladesh. American Journal of Water Science and Engineering. Vol. 4, No. 1, 2018, pp. 9-15. doi: 10.11648/j.ajwse.20180401.12

Received: December 30, 2017; Accepted: February 11, 2018; Published: March 6, 2018

\begin{abstract}
Water is critical for human endurance, socio-economic improvement of the state and protection of its natural environment. This paper analyzes the present day state of affairs and problems of water resources in Bangladesh. The goal of this study is aimed on sustainable development of water assets in Bangladesh. The information is collected from the secondary sources and statistics available such as books and internet.
\end{abstract}

Keywords: Water Resources, Sustainable Development, Socio-economic Development, Bangladesh

\section{Introduction}

Water Resources Bangladesh is endowed with plenty of surface and groundwater resources. The surface water resources comprise water available from flowing rivers and static water bodies as ponds, beels and haors. Surface water inflows of the country vary from a maximum of about $140,000 \mathrm{~m} 3 / \mathrm{s}$ in August to a minimum of about 7,000 m3/s in February. Two main rivers, the brahmaputra and the ganges account for more than $80 \%$ of streamflows. The highest flood discharge of the Ganges observed at hardinge bridge in 1987 was $76,000 \mathrm{~m} 3 / \mathrm{s}$ and that of the Brahmaputra observed at Bahadurabad in 1988 was $98,600 \mathrm{~m}^{3} / \mathrm{s}$. the minimum discharges of the rivers are $261 \mathrm{~m}^{3} / \mathrm{s}$ and 2800 $\mathrm{m} 3 / \mathrm{s}$, respectively. The average daily flow of the Ganges is about $10,874 \mathrm{~m}^{3} / \mathrm{s}$, which reduces to $1366 \mathrm{~m} 3 / \mathrm{s}$ during season and increases to $32,00 \mathrm{~m}^{3} / \mathrm{s}$. The highest flow is about $44,000 \mathrm{~m} 3 / \mathrm{s}$ which is usually received in August. The annual average discharge of the Meghna at Bhairab Bazar is approximately $4,800 \mathrm{~m} 3 / \mathrm{s}$ and the maximum flow occurs generally around mid-August. The alluvial aquifer systems of Bangladesh are some of the most productive ground water reservoirs. The aquifer system generally consists of three lithological units, an upper silts clay and silt layer, a middle layer of fine to very fine sand, and a lower layer of fine to coarse sand constituting the main aquifer. The upper layer is usually 30 to $60 \mathrm{~m}$ thick, the middle layer is about $20 \mathrm{~m}$ thick and lower aquifer is about $100 \mathrm{~m}$ thick. The transmissibility of the main aquifer ranges from $\% 00$ to $2500 \mathrm{~m} 2 /$ day and the storage coefficient varies from less than one percent to 15 percent. At places water table can be found within a few meters below the ground surface. Bangladesh also receives plenty of rainfall in the monsoon extending from June to October. The country receives plenty of rainfall and the amount of annual rainfall ranges from about $3200 \mathrm{~mm}$ in the northeast to about $1600 \mathrm{~mm}$ in the southwest region. Over the annual cycle rainfall exceeds evapotranspiration by about $10 \%$ in the northeast and southeast region whereas they are almost equal in northwest and in the southwest evapotranspiration exceeds rainfall by about $10 \%$. During the seven-month dry season extending from November to May, evapotranspiration is greater than average rainfall except in the northeast region. Most of the winter crops and some summer crops can be grown under rain fed conditions. Generally, it can be said that Bangladesh has plenty of water but its uneven distribution, overabundance in monsoon often causes catastrophic floods and scarcity in dry season causes severe drought conditions leading to loss of crops, livestock, public health problems and environmental degradation. [2]

\section{Overview of Bangladesh}

Bangladesh is a small country in south Asia surrounded by India and Myanmar. The southern part touches the Bay of Bengal (Figure 1). It is one of the most densely populated countries in the world. The population is almost about 160 
million with a growth rate approaching $1.6 \%$. The area of Bangladesh is about 148,460 sq. km. Approximately. $70 \%$ land is considered for irrigation purposes and 18,290 sq. km is covered with water. Bangladesh is situated in the tropical region. The average temperature varies from almost $18^{\circ} \mathrm{C}$ to $28^{\circ} \mathrm{C}$ and the highest precipitation is around $\% 32 \mathrm{~mm}$ in July and lowest in January almost $14 \mathrm{~mm}$ [10].

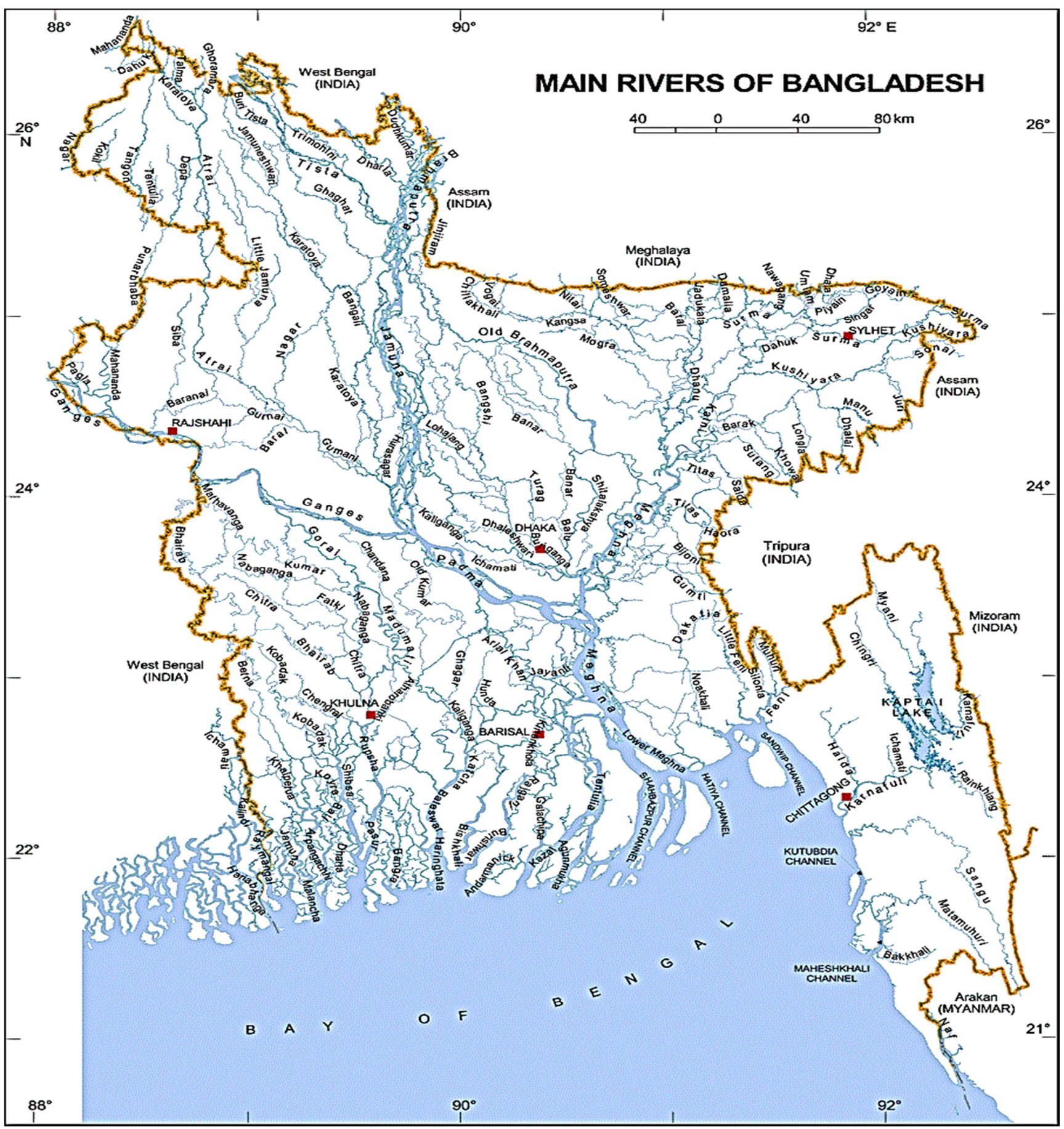

Figure 1. Main Rivers of Bangladesh [4].

\section{Current Situation of Water Resources in Bangladesh}

Water is needed for meeting consumptive demands, which include agricultural, domestic and industrial use and nonconsumptive demands which comprise in-stream use (navigation, fisheries, salinity control and dilution of pollution) and water required for ecological protection and wetland preservation. For proper planning, development and utilization of water resources, correct assessment of available water resources is essential but difficult. Water becomes really a scarce resource in Bangladesh during the dry months of the year and maximum water demand occurs in March. 
First assessment of availability and demand of water resources in the critical month of March was made by the Master Plan Organisation (now Water Resources Planning Organisation) and presented in the National Water Plan prepared in 1986. In 1991 MPO updated the National Water Plan together with the demand and supply of water. Gross water demand is based on the irrigation requirement, salinity control in the estuaries, riverine fisheries, inland navigation, fisheries and salinity control, and domestic and industrial uses. There are about 7.56 Mha (million hectares) of cultivable land of which about 6.9 Mha of agricultural land can be brought under irrigation at full development by the year 2018. The total water requirement has been estimated at 24,370 $\mathrm{Mm}^{3}$ (million cubic metre) which includes 14,209 $\mathrm{Mm} 3$ for agriculture, 9,910 Mm3 for navigation and 170 $\mathrm{Mm} 3$ for domestic and industrial use. The total water supply in this month is $23,490 \mathrm{Mm}^{3}$ which comprises $\%, 360 \mathrm{Mm}^{3}$ of groundwater, 6,390 Mm3 from regional rivers, beels and haors and $11,740 \mathrm{Mm}^{3}$ from main rivers. Agricultural water requirement is $8.6 \%$ of the total, navigation, salinity control and fisheries demand $40.7 \%$ and domestic and industrial need accounts for only $0.7 \%$ of total demand. Out of these entire requirements, $77.2 \%$ is expected to be provided by surface water and the balance $22.8 \%$ is expected to come from groundwater. Water balance, shown in the Table, was estimated by the MPO in 1991 for the month of March for a 1983 benchmark year followed by 1990 and the likely position in the years 2005 and 2018. The year 2018 was contemplated as the projected earlier possible date for full development of the Ganges and Brahmaputra barrage projects. [3]

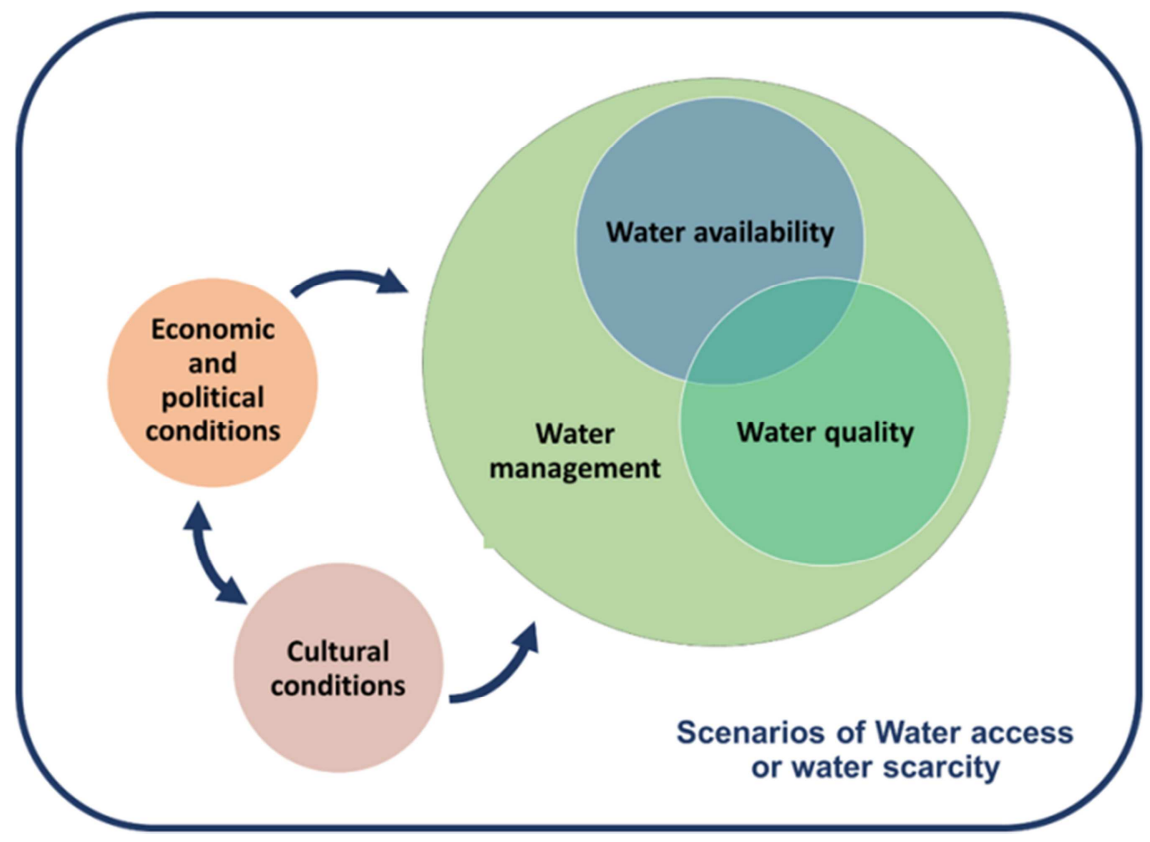

Figure 2. Scenarios of Water Scarcity or Water access.

The water balance shows that on an annual basis more surface water flows through Bangladesh into the Bay of Bengal than is needed for all consumptive and nonconsumptive uses. In the benchmark year 1983, the inflow of $3,990 \mathrm{~m} 3 / \mathrm{s}$ of the Brahmaputra river accounts for $69 \%$ of the total inflow. The Ganges contributes about 15\%. All other measured tributary inflows account for only $7.7 \%$, and the unmeasured tributary inflows (net) are estimated to be $8.3 \%$. The net unmeasured inflows represent the summation of all unmeasured inflows and outflow to the system between Bahadurabad on the Brahmaputra (about $80 \mathrm{~km}$ downstream from the Indian border), Hardinge Bridge on the Ganges (about $30 \mathrm{~km}$ east of the Indian border) and Barura just below the confluence of the two rivers. By 2005, approximately $600 \mathrm{~m} 3 / \mathrm{s}$ was used by diversion into existing canal system by pumps operating 12 hours per day. It would be possible to divert $1830 \mathrm{~m} 3 / \mathrm{s}$ by means of constructing barrages in future over the Brahmaputra and the Ganges rivers. Realization of surface water potential is constrained by a number of factors although an immense quantity of surface water flows through Bangladesh. Most importantly there are no opportunities for surface storage and little scope for gravity diversion without any barrages over the Brahmaputra and the Ganges. Under the existing conditions, annual outflows from these two major rivers to the Bay of Bengal are essentially equal to the inflows from India. Amount of present diversion within Bangladesh is far less than the errors of measurement. A water balance study for March, the most critical dry month, indicates that even relatively high abstraction in this month for irrigation the net diversion is about only $\% \%$ of the inflows. Water balance, shown in the Table, was estimated by the MPO in 1991 for the month of March for a 1983 benchmark year followed by 1990 and the likely position in the years 2005 and 2018. The year 2018 was contemplated as the projected earlier possible date for full development of the Ganges and Brahmaputra barrage projects. [2, 14]

Water Resources: 
Table 1. Water Inflows in Bangladesh.

\begin{tabular}{|c|c|c|c|c|}
\hline Water Inflow & 1983 & 1990 & 2005 & 2018 \\
\hline \multicolumn{5}{|l|}{ Border Inflows (m3/s): } \\
\hline Brahmaputra & 3990 & 3900 & 3900 & 3800 \\
\hline Ganges & 870 & 770 & 836 & 836 \\
\hline \multicolumn{5}{|l|}{ Tributary Inflows $(\mathrm{m} 3 / \mathrm{s})$ : } \\
\hline Measured & 450 & 370 & 284 & 284 \\
\hline Unmeasured (net) & 480 & 790 & 480 & 480 \\
\hline Total Inflows (m3/s) & 5790 & 5830 & 5500 & 5400 \\
\hline \multicolumn{5}{|l|}{ Diversions $(\mathrm{m} 3 / \mathrm{s})$ : } \\
\hline Normal Diversions & 200 & 200 & 200 & 130 \\
\hline New pumps and improved offtakes & - & - & 600 & 370 \\
\hline \multicolumn{5}{|l|}{ Possible diversions by barrage: } \\
\hline from Brahmaputra & - & - & - & 1000 \\
\hline from Ganges & - & - & - & 830 \\
\hline Total diversions (m3/s) & 200 & 200 & 800 & 2330 \\
\hline Outflows to the Bay of Bengal (m3/s) & 5590 & 5630 & 4700 & 3070 \\
\hline Source: http://en.banglapedia.org/index.php?title=Water_Resources $[2,13]$ & & & & \\
\hline
\end{tabular}

Bangladesh has become increasingly dependent on groundwater sources for meeting irrigation needs. Farmers have to use groundwater to grow Boro rice in the winter when there is little rainfall and that local rivers and water supply channels dries up. Tran-boundary inflows of rivers are also diminishing alarmingly due to progressively increasing withdrawal in the upper riparian countries. [3]

\section{Main Causes of Water Problems in Bangladesh}

Bangladesh has big water problems and challenges now, and they are likely to grow greater with growing

population, development, and climate change. Water is central to the life and culture of Bangladesh: to quote Razzaq (1980) 'The character of Bangladesh and its people is dominated today, as it has always been dominated, by the river system and the water it carries or helps carry'. To that, we would add the importance of groundwater, so central (as we will describe in this report) to the new-found food security of a people with a history of famines [9]. A detailed discussion has been provided below to clarify the causes of Water problems in Bangladesh:

\subsection{Water Pollution}

Water pollution is yet another cause of water scarcity. The sources of water pollution include pesticides and fertilizers that wash away from farms, industrial and human waste that is directly dumped into rivers without treating it in water treatment plant. Oil spill on the ground, waste water leakage from landfills can seep underground and may pollute the groundwater making it unfit for human consumption. [7]

\subsection{Overpopulation}

The rapid increase in human population combined by massive growth in industry sector have transformed water ecosystems and resulted in loss of biodiversity. As population is increasing at an ever increasing rate, the demand for new resources will result in additional pressure on freshwater sources. [7]

\subsection{Agriculture}

Agriculture uses majority of available freshwater. The sad thing is that about $60 \%$ of this water gets wasted due to inefficient agriculture methods and leaky irrigation systems. In addition to this, pesticides and fertilizers are washed away in rivers and lakes that further affect human and animal population. [7]

\section{Bangladesh Water Policy}

\subsection{Existing Policies for Water Management}

Bangladesh has various national policies for different key sectors to accelerate the balanced way of development. There are several policies and acts for formulating the rules and regulations on general usage on water. The major policies and acts are:

a. National Water Policy (1999);

b. Coastal Zone Policy (2005);

c. Coastal Development Strategy (2006);

d. National Water Management Plan: Development Strategy (2011);

e. Bangladesh Water Act 2013. [1]

\subsection{Bangladesh Water Act 2013}

It is an act to make provisions for development, management, abstraction, distribution, use, protection and conservation of national resources in an integrated approach. The act is applicable for the surface water, ground water, sea water, rain water and water in the atmosphere in the territory of Bangladesh. For the purpose of this act a small council which is called "National Water Resource Council" presided by the Prime Minister has been constituted. Under this act, several exchanges can be possible at government level. Those are:

1. Exchange and assess any information of common water 
resources;

2. Joint research on international rivers

3. Prevention measures for chemical and organic pollution;

4. Measures for the distribution of the water of international rivers;

5. Organization of educational and training programs on water resources. [1]

\subsection{Water Management Policy Making in Bangladesh}

The Ministry of Water Resources (MOWR) is the apex body of the government of Bangladesh for development and management of the country's water resources. MOWR formulates policies, plans, strategies, guidelines, instructions and acts, rules and regulations related to water management, as well as regulate and control the institutions reporting to it. MOWR prepares and implements development projects related to flood control, drainage and irrigation, riverbank erosion control, delta development and land reclamation, and provides facilities by constructing barrages, regulators, sluices, canals, cross-dams, embankments and sea dykes. The Bangladesh Water Development Board (BWDB) is the implementing arm of the MOWR responsible for the collection, processing and dissemination of hydrological data. MOWR provides flood forecasting information through the Flood Forecasting and Warning Centre (FFWC) of the BWDB. The Ministry is also responsible for Guidelines for Participatory Water Management (GPWM). Through its macro-planning arm, the Water Resources Planning Organization (WARPO), the ministry has prepared the National Water Policy, Coastal Zone Policy, National Water Resources Database (NWRD), National Water Management Plan (NWMP) and Integrated Coastal Resources Database (ICRD). [1,12]

Under the Ministry of Water Resources, WARPO deals with nationwide water resources planning, descending from a joint government of Bangladesh-World Bank Mission in 1970 which recommended formulation of a National Water Plan (NWP) based on a systematic assessment of resources and demand. The government thus created the Master Plan Organization (MPO) under the Ministry of Water Resources in 1983 and initiated the NWP project to formulate a perspective plan (1985-2005) for water resources development. Completed in 1987, the NWP project made a comprehensive assessment of water resources from both surface and groundwater sources, developed planning models and analytical tools, and recommended strategies and programmes for the country's water sector. NWP proposed to institutionalize the process of water planning and long-term water resource management, and, following this recommendation, WARPO was established in 1992 to carry out continuous national water planning. A National Water Policy was enacted in 1999 giving WARPO the role of an apex planning body in the water sector. WARPO was thereby mandated to: act as a secretariat to the Executive Committee to the National Water Resources Council, prepare the National Water Management Plan, update the National Water
Resources Database, review proposals and provide technical support to the Planning Commission and monitor and evaluate the state of water resources in Bangladesh. The Bangladesh Water Development Board (BWDB) had its antecedents in the water wing of the East Pakistan Water and Power Development Authority, which was the principal agency for managing water resources, tasked with flood control, drainage and irrigation projects. When Bangladesh gained its independence, the authority was restructured in 1972 within two different organizations to deal with water and power separately, and BWDB was created as a fully autonomous organization. Following enactment of the BWDB Act in 2000, the board is guided by the 1999 National Water Policy (NWPo) and the 2004 National Water Management Plan (NWMP). Policymaking and overall management of the BWDB is now vested in a Governing Council headed by the Minister, MOWR. [1]

The Indo-Bangladesh Joint Rivers Commission was a bilateral working group established pursuant to a 1972 joint declaration of the Prime Ministers of Bangladesh and India concerning cooperation on water-sharing, irrigation and flood control. The studies and reports of the commission contributed to bilateral agreements on the sharing of Ganges waters in 1975, 1978 and, finally, in 1996. Since its establishment, the commission has held 37 meetings, mainly on the sharing of water from common rivers, transmission of flood-related data from India to Bangladesh, construction and repair of embankments and bank protection works along border rivers, India's planned River Linking project and Tipaimukh Dam project and, finally, construction of the Mahananda Barrage, which is built across the Mahananda River linked with the Teesta by the $25 \mathrm{~km}$ long TeestaMahananda link canal. Subsequent to the 1972 declaration, the government of Bangladesh established the Joint Rivers Commission (JRC), Bangladesh to address issues related to the sharing and management of water from Transboundary Rivers. The activities of the JRC Bangladesh include negotiation with coriparian countries on the development, management and sharing of water resources of common rivers, bilateral discussions with India and meetings of the Indo-Bangladesh Joint Rivers Commission as described above, and monitoring of the Ganges waters at Farakka Barrage (in India) and Hardinge Bridge (in Bangladesh) during 1 January to 31 May every year as per the provisions of the Ganges Water Treaty. The JRC Bangladesh also carries out joint work with Nepal harnessing common water resources and mitigating floods and flood damage, and cooperates with China on enhancement of flood forecasting capabilities through exchange of flood-related data for the Yarlung Tsangpo (Brahmaputra) and training in relevant technical fields. [1]

\section{Sustainable Development of Water Resources in Bangladesh}

The SDG 6 proposes to ensure availability and sustainable 
management of water and sanitation for all. A specific target is to achieve universal and equitable access to safe and affordable drinking water for all by 2030 .

The Challenges and impediments to sustainable development of water resources in Bangladesh can be divided in to transboundary and domestic categories. The geographic region known as Bangladesh is but a small part of the Ganges-Barhmaputra-Meghna (GBM) basins, which occupy 1.7 million $\mathrm{km}^{2}$ area in China, Nepal, Bhutan, India, and Bangladesh. Only $7.4 \%$ of the GBM basins are located in Bangladesh, yet $27 \%$ of the total population lives here. Since Bangladesh is located at the downstream part of the GBM basins, the state of the water, both in terms of quantity and quality, is directly tied to the activities in the upper region of these basins. All $\% 7$ major rivers in Bangladesh originate outside of the country; 54 rivers flow from India and 3 rivers flow from Myanmar. Of the $\% 7$ trans-boundary rivers, there exists only one bilateral treaty between India and Bangladesh on sharing of the Ganges River flow during lean season. Despite the existing treaty, Bangladesh did not receive the agreed amount for most of the period during 2008-12. [3]

Bangladesh's dependence for flow of water from upper riparian countries is the root cause of vulnerability of this precious resource. Of the total annual renewable flow of 1,211 billion cubic meters (BCM) of water in the GBM basins, only $105 \mathrm{BCM}(8 \%)$ originate within the territory of Bangladesh. Unilateral control of surface water flow in the GBM basins by the upper riparian countries lies at the heart of insecurity of water resources in Bangladesh and is a major impediment to sustainable development of water resources So far, more than 600 large dams have been built or are in some stage of construction or planning in the geologically active Himalayan Mountains In recent years, India and China have made plans to build 150 large hydropower projects on the Brahmaputra River, 80 of which are located in Arunachal Pradesh of India that is located upstream of Bangladesh, and is considered the most seismically active region in India. In addition, Indian government is actively pursuing the inter-linking of rivers project (ILRP). The ILRP envisages linking 37 major rivers with 31 artificial link canals (totaling $14,000 \mathrm{~km}$ in length), to transfer a total of 173 billion cubic meters of waters from surplus watersheds (e.g. Ganges-Brahmaputra), to the water-deficit watersheds (e.g., Mahanadi, Godavari, Kaveri, and Tapi) in the southern and western parts of the country. [3]

\section{Challenges}

1. Poor Management

2. Lack of Investment

3. Lack of the Political and Administration policy

4. Lack of Earthwork

5. Completion of work

6. Lack of Technology $[5,6]$

\section{Recommendations}

As the lower riparian state of three major river systems, Bangladesh should work with its neighbors towards overall basin management, with an early focus on the different hydrological regions and promoting information exchange. Although Signature of Ganges Water Treaty in 1996 is an important milestone, continued efforts are needed to secure Bangladesh's share of the flows of the other $\% 3$ transboundary rivers. The National Water Management Plan has to address and balance the conflicting needs of too much water in monsoon and too little in the dry season which would need tapping the resources of both surface and ground water. $[8,11]$

\subsection{Water Management}

Water management by the use of regulations and policies can help reduce water scarcity. The regulations and policies can address the water-related problems including aspects such as water reuse, water resource management, water rights, industrial water use, wetland restoration, domestic water supplies, water pollution, and others. In precise, water management has the capability of addressing human interventions and the various natural events in connection with resources and the long-term water policy decisions on the environment and economy.

\subsection{Infrastructure Repair and Maintenance}

One of the key ways of solving the problem of water scarcity can be through infrastructure repair and maintenance of water channels. Leaking pipes and sewage systems normally lead to water wastage and contamination respectively. If these infrastructures are left unattended to over time, the cumulative effects can create water shortages. Millions of liters of water are lost yearly in various regions of the world owing to leakages and sewer contamination, creating water shortages.

\subsection{Investment}

Government must provide funds to the companies, which are really committed to the work, are facing shortage of funds. As soon as possible the investment gets injected this industry will grow.

\subsection{Training of Personnel}

The government should facilitate the trainings of the personnel for the exploration of the resource for the future development and economy as the economy is the backbone of development.

\subsection{Proper Auditing}

Audit system should be inducted for the monitoring and the proper usage of the funds.

\subsection{Proper Infrastructure}

Government must develop proper infrastructure in order to 
develop these. There is urgent need to build barrages, provide proper technology.

\section{Conclusion}

Public Authorities of the Local Region under local government as well as globally operational nongovernmental Organizations (NGOs), and International Organizations under the flag of UNO should take the responsibility of Water Management and resource accumulation because water is life and there is no survival without water. The disagreement of opinion on structuring of water resources has deprived the country of storing the excess water for the highly important usages such as agricultural and electricity generation. However, this could be overcome by vision and planning, which is a scarce commodity here. Instead of controversial big dams several small reservoirs could be constructed, had a pragmatic approach prevailed among the decision making. Bangladesh, as a nation, is privileged and fortunate to have plenty of this vital resource. The quality of this valuable resource, however, is deteriorating rapidly. Only through a better understanding of the sources of pollution and processes that affect the quantity and quality of water we can save this precious resource for current and future generations. Understanding the problem, however, it's only half of the solution. The other half of the solution lies in collective actions. The populace in the GBM basins can play a role in preserving the quality of water. All countries in the GBM basins need to join hands to protect this valuable resource, as well as our very existence as an educated society.

\section{References}

[1] Water Management in Bangladesh - cuts citee http://www.cuts-citee.org/SDIP/pdf/Policy Brief on WaterWater_Management_in_Bangladesh.pdf.

[2] National encyclopedia of Bangladesh, http://en.banglapedia.org/index.php?title=Water_Resources.

[3] Md. Khalequzzaman, Sustainable development of water resources in Bangladesh in the context of planetary boundaries and environmental performance index, Haven University, Lock Haven, PA, 17745. http://ic-sd.org/wpcontent/uploads/sites/4/2016/06/Sustainable_development_of water_resources_in_Bangladesh_Full_Paper.pdf.
[4] https://www.the bangladesh.net/rivers-of-bangladesh.

[5] National Water Policy - FAOLEX Database http://extwprlegs1.fao.org/docs/pdf/bgd146075.pdf.

[6] Shahadat Hossain, Mir Md Tamim \& M. Rahman Coping with new Challenges in Water Resources Management in Bangladesh.

https://www.researchgate.net/publication/258114011_COPIN G WITH NEW CHALLENGES IN WATER RESOURCE S_MANAGEMENT_IN_BANGLADĒESH.

[7] Matthew Chadwick and Anjan Datta, Water Resource Management in Bangladesh, A Policy Review LivelihoodPolicy Relationships in South AsiaWorking Paper 1.

[8] Abu Musa Md. Motaher AHMED and Kingshuk ROY, Utilization and Conservation of Water Resources in Bangladesh, http://www.nourin.tsukuba.ac.jp/ tasae/2006/Bangladesh.pdf.

[9] Bangladesh Integrated Water Resources Assessment: final Report, A report prepared by CSIRO, WARPO, BWDB, IWM, BIDS and CEGIS for the Department of Foreign Affairs Australia Aid -CSIRO Research for Development Alliance, May2014.

[10] Ayesha Sharmin, Water and wastewater in Bangladesh, current status and design of a decentralized solution, Postal address, Lund University.

http://lup.lub.lu.se/luur/download?func=downloadFile\&record OId $=8895656 \&$ fileOId $=8895752$.

[11] Ashim Das Gupta, Mukund Singh Babel, Xavier Albert \& Ole Mark. Water Sector of Bangladesh in the Context of Integrated Water Resources Management: A Review, https://www.researchgate.net/publication/230557502_Water_S ector_of_Bangladesh_in_the_Context_of_Integrated_Water_R esources_Management_A_Review

[12] A H M Kausher, Water Resources Management in Bangladesh: Past, Present and Future Project Director \& Field Manager Development of an Investment Plan to support The Implementation of Bangladesh Delta Plan 2100 (Word Bank).On behalf of the Consortia of Castalia US, ARCADIS, NL, SMEC, Bangladesh).

[13] Md. Shah Alamgir, Malik Fida Khan and Stephen Brichieri Colombi: Sustainable Development of National Water Resources Database in Bangladesh and Its Management Issues International Conference on Spatial Information for Sustainable Development https://www.fig.net/resources/proceedings/2001/nairobi/alamg ir-khan-colombi-TS5-2.pdf

[14] Golam Rasul and A. K. M Jahir Uddin Chowdhury, Equity and Social Justice in Water Resource Management in Bangladesh. 